\title{
Best Practices in Designing and Developing Online Courses at the Canadian Foreign Service Institute
}

\author{
S. Wasty and D. Renié
}

\begin{abstract}
This paper describes the approach and considerations taken into account while designing and developing online courses at the Canadian Foreign Service Institute at the Department of Foreign Affairs and International Trade Canada and how research is applied in achieving desired goals and work objectives. It details what is common to the design and development of online courses in the application of lessons from educational literature in a practical setting, in relating to concepts of eLearning and instructional design: doing a needs assessment; gathering content and working with SMEs; developing a Master Design Chart, detailed storyboard; designing activities and an overall interactive interface; and finally, conducting evaluations. The linkages between theory and practice include the applications of various theoretical propositions, such as Alessi \& Trollip's eight steps to address computer-based instructional design; Gagne's nine events of instruction; Mayer's ten research-based principles of multimedia learning; Dick \& Carey's six stages of formative evaluation; and Kirkpatrick four levels evaluation model. The paper proposes five stages of online course development employed at the Canadian Foreign Service Institute as a means of best practices for corporate training.
\end{abstract}

Index Terms - Canada, education, eLearning, instructional design.

\section{INTRODUCTION}

The Canadian Foreign Service Institute (CFSI) provides internal learning opportunities at the Department of Foreign Affairs and International Trade Canada (DFAIT). As the centre of educational and training expertise, CFSI provides services for all staff at headquarters and at missions abroad, as well as for other government departments. Some of the services include professional development programs; management development programs; training on corporate systems; foreign language training; and intercultural effectiveness training.

In line with learning trends and recognizing the importance of building a technologically literate workforce [1], CFSI has undertaken steps to increase time and cost efficiency, as well as to ameliorate post-training results. The traditional methodology of classroom based instruction conducted either at headquarters or at hub locations around the world was often both time-consuming as well as costly, and did not consistently bring about the desired learning outcomes. A systematic evaluation and review of learning strategies led to an institutional shift in functional philosophy to maximize training through developing effective online learning courses. CFSI has since evolved towards a blended learning approach, with an increasing focus on eLearning

Manuscript received March 15, 2011. mechanisms. Not only are factors such as long term economic benefit and convenience still valid, but eLearning poses numerous benefits, including helping to streamline processes and training, thereby allowing for better measures of quality assurance in maintaining a standardized delivery for all users.

The Centre for Learning Advisory Services, eLearning and Administration (CFSA) is an example of this learning evolution. As the name would suggest, an eLearning team was established to help guide new online courses using innovative approaches. The list of CFSA developed tools, solutions and online courses is extensive, but some notable ones launched in the past three years include Advocacy; Islam and Muslim Communities: Perspectives for Foreign Policy; New Way Forward; Orientation to Consular Services and Emergency Management; Orientation to the Trade Commissioner Service; and Sustainable Development. Online courses are managed by qualified Education Specialists, who play multiple roles as project managers, instructional designers and online learning advisors.

\section{FRAMEWORK OF COURSES PRODUCED}

The objective of developing online courses is to introduce learners to issues that they would encounter on the job and, as such, for improved work performance and achieving desired objectives. The online courses are offered to members of DFAIT Canada, including staff at postings around the world, as well as staff from other government departments. All tools and courses are developed in English and French, in accordance to the bilingual requirements of the federal government as per the Official Languages Act.

The content, layout and interface vary for all of the different tools and online courses produced. Depending on the nature of the course, some solutions are with advanced programming tools and software, whereas others are with low-cost, self-authoring tools for rapid eLearning. As well, in terms of courses linked to the blended learning model, some online courses serve as stand alone whereas others fulfill a dual role in being stand alone but also pre-requisites for classroom courses. Nevertheless, there remains a level of consistency throughout and many commonalities in their respective design and development in adhering to specific learning standards and considerations. Government standards such as 'Common Look and Feel' are complied with; these include accessibility considerations and design specifications so as to ensure disabilities are not obstacles for learning opportunities.

Tasks and responsibilities in the design and development lifecycle of the online courses can be divided into five 
principal stages; each stage comes into effect as per course requirements and given the provision and allocation of the required time and resources. Fig. 1 showcases the different stages and their associated tasks.

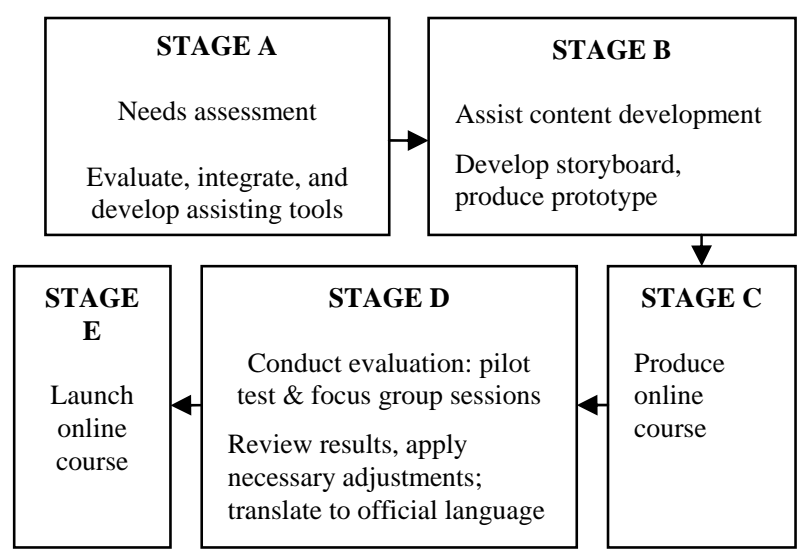

Fig. 1. 5 stages of Online Course Development

\section{Concept of eLearning}

The adopted definition of eLearning is content and instructional methods delivered on a computer, and designed to build knowledge and skills related to individual or organizational goals [2]. This definition addresses three factors, which can be specifically contextualized for this project with Table 1.

Online learning is understood to be a hypermedia-based instructional program, which utilizes the attributes and resources of the internet to create a meaningful learning environment where learning is fostered and supported [3]. Accordingly, the following basic elements are considered in the process of instructional design: learner-centered; oriented towards knowledge objectives; has practical performance; and directed towards learner outcomes that are observable and measurable. Some additional advantages of eLearning include the provision of cost savings, learning flexibility, unified and updated information, anytime anywhere learning [4]. All of these factors are in accordance with the desired outcomes of CFSI.

\section{Instructional Design}

The development of online courses requires a process that can help guide the project systematically. A process that provides a good strategy to develop courses is Alessi \& Trollip's 8 steps to address computer-based instructional design: define the purpose; collect resource material; generate ideas for the lesson; organize the ideas for the lesson; produce lesson display on paper; flowchart the lesson; program the lesson; and evaluate quality and effectiveness [5].

TABLE I: CONTEXTUALIZATION OF CLARK'S DEFINITION OF ELEARNING

\begin{tabular}{|l|l|l|}
\hline What & $\begin{array}{l}\text { Training delivered in } \\
\text { digital form. }\end{array}$ & $\begin{array}{l}\text { Courses pertaining to tasks and } \\
\text { responsibilities of DFAIT } \\
\text { Canada. }\end{array}$ \\
\hline How & $\begin{array}{l}\text { Content and instructional } \\
\text { methods to help learn the } \\
\text { content. }\end{array}$ & $\begin{array}{l}\text { Interactive courses with } \\
\text { practical environments and } \\
\text { simulation of real-life } \\
\text { situations. }\end{array}$ \\
\hline Why & $\begin{array}{l}\text { Improve organizational } \\
\text { performance by building } \\
\text { job-relevant knowledge } \\
\text { and skills in workers. }\end{array}$ & $\begin{array}{l}\text { To help DFAIT Canada staff } \\
\text { better perform their jobs, by } \\
\text { providing globally accessible } \\
\text { training effectively and } \\
\text { efficiently at a lower cost. }\end{array}$ \\
\hline
\end{tabular}

Prior to engaging in learning, adults need motivation in knowing why they need to learn something and to learn that which they need to be able to do in order to cope effectively with their real-life situations [7]. As such, learners should be engaged every step of the way [8]. The course design must contribute to the development of a learning environment and proposes that contextual learning objectives will help learners maintain a positive connection with what is being taught, reinforcing the concept of stimulating prior learning [9].

To avoid a popular misconception in regard to online education in which online courses are simply print-based material pasted into an electronic format [10], CFSA's work is based upon Gagne's nine events of instruction, a widely used instructional design procedure when designing online learning [3]. Table 2 explains the events and how they are contextualized in CFSA projects and Table 3 features ten research-based principles of multimedia learning that are maintained throughout the course design [11].

TABLE II: GAGNE’S 9 EVENTS OF INSTRUCTION

\begin{tabular}{|c|c|c|}
\hline $\begin{array}{c}\text { Instructional } \\
\text { Event }\end{array}$ & $\begin{array}{c}\text { Internal } \\
\text { Mental Process } \\
\end{array}$ & Contextualized in Project \\
\hline $\begin{array}{l}\text { 1.Gaining } \\
\text { attention }\end{array}$ & $\begin{array}{l}\text { Stimuli } \\
\text { activates } \\
\text { receptors }\end{array}$ & $\begin{array}{l}\text { Users are informed as to how } \\
\text { the course is relevant to their } \\
\text { roles, responsibilities and work. } \\
\text { There are numerous images and } \\
\text { audiovisual features and } \\
\text { activities. }\end{array}$ \\
\hline $\begin{array}{l}\text { 2.Informing } \\
\text { learners of } \\
\text { objectives }\end{array}$ & $\begin{array}{l}\text { Creates level } \\
\text { of expectation } \\
\text { for learning }\end{array}$ & $\begin{array}{l}\text { Subject overview and learning } \\
\text { objectives are provided right at } \\
\text { the start. }\end{array}$ \\
\hline $\begin{array}{l}\text { 3.Stimulating } \\
\text { recall of prior } \\
\text { learning }\end{array}$ & $\begin{array}{l}\text { Retrieval and } \\
\text { activation of } \\
\text { short-term } \\
\text { memory }\end{array}$ & $\begin{array}{l}\text { Material is referred to reference } \\
\text { readings. Activities would help } \\
\text { recall content that learners had } \\
\text { gone through. }\end{array}$ \\
\hline $\begin{array}{l}\text { 4.Presenting } \\
\text { the stimulus }\end{array}$ & $\begin{array}{l}\text { Selective } \\
\text { perception of } \\
\text { content }\end{array}$ & $\begin{array}{l}\text { Real-life scenarios and } \\
\text { activities are provided. }\end{array}$ \\
\hline $\begin{array}{l}\text { 5.Providing } \\
\text { "learning } \\
\text { guidance" }\end{array}$ & $\begin{array}{l}\text { Semantic } \\
\text { encoding for } \\
\text { storage } \\
\text { long-term } \\
\text { memory } \\
\end{array}$ & $\begin{array}{l}\text { Navigational cues. Clear } \\
\text { instructions through procedural } \\
\text { tasks are provided. }\end{array}$ \\
\hline $\begin{array}{l}\text { 6.Eliciting } \\
\text { performance }\end{array}$ & $\begin{array}{l}\text { Responds to } \\
\text { questions to } \\
\text { enhance } \\
\text { encoding and } \\
\text { verification }\end{array}$ & $\begin{array}{l}\text { Activities include multiple } \\
\text { choice, true/false, } \\
\text { fill-in-the-blanks, select all and } \\
\text { matching questions. }\end{array}$ \\
\hline $\begin{array}{l}\text { 7.Providing } \\
\text { feedback }\end{array}$ & $\begin{array}{l}\text { Reinforcement } \\
\text { and assessment } \\
\text { of correct } \\
\text { performance }\end{array}$ & $\begin{array}{l}\text { Informative feedback to both } \\
\text { correct and incorrect responses } \\
\text { in activities and assessment are } \\
\text { provided. }\end{array}$ \\
\hline $\begin{array}{l}\text { 8.Assessing } \\
\text { performance }\end{array}$ & $\begin{array}{l}\text { Retrieval and } \\
\text { reinforcement } \\
\text { of content as } \\
\text { final } \\
\text { evaluation }\end{array}$ & $\begin{array}{l}\text { Activities and assessments are } \\
\text { included in the modules so } \\
\text { learners can gauge their } \\
\text { understanding. }\end{array}$ \\
\hline $\begin{array}{l}\text { 9.Enhancing, } \\
\text { retention and } \\
\text { transfer }\end{array}$ & $\begin{array}{l}\text { Retrieval and } \\
\text { generalization } \\
\text { of learned skill } \\
\text { to new } \\
\text { situation }\end{array}$ & $\begin{array}{l}\text { Ample cases and activities are } \\
\text { provided so that learners can } \\
\text { have multiple examples to } \\
\text { practice. }\end{array}$ \\
\hline
\end{tabular}

Thus, the projects are practically designed so as to maximize learner control over their own learning. At the same time, they help provide options in learning paths so that 
learners are not affected by cognitive overload and possible disorientation [10] [12], by way of the focus on the primary objectives being shifted to less relevant ones [13].

TABLE III: MAYER'S 10 RESEARCH-BASED PRINCIPLES OF MULTIMEDIA LEARNING

\begin{tabular}{|l|l|}
\hline $\begin{array}{l}\text { Multimedia } \\
\text { principle }\end{array}$ & $\begin{array}{l}\text { People learn better from words and } \\
\text { pictures than from words alone. }\end{array}$ \\
\hline $\begin{array}{l}\text { Contiguity } \\
\text { principle }\end{array}$ & $\begin{array}{l}\text { People learn better when corresponding } \\
\text { words and pictures are presented near } \\
\text { rather than far from each other in time or } \\
\text { on the screen. }\end{array}$ \\
\hline $\begin{array}{l}\text { Coherence } \\
\text { principle }\end{array}$ & $\begin{array}{l}\text { People learn better when extraneous } \\
\text { words, pictures, and sounds are excluded } \\
\text { rather than included. }\end{array}$ \\
\hline $\begin{array}{l}\text { Modality } \\
\text { principle }\end{array}$ & $\begin{array}{l}\text { People learn better from words and } \\
\text { pictures when words are spoken rather } \\
\text { than printed. }\end{array}$ \\
\hline $\begin{array}{l}\text { Redundancy } \\
\text { principle }\end{array}$ & $\begin{array}{l}\text { People learn better from animation and } \\
\text { narration than from animation, narration, } \\
\text { and on-screen text. }\end{array}$ \\
\hline $\begin{array}{l}\text { Personalizatio } \\
\text { n principle }\end{array}$ & $\begin{array}{l}\text { People learn better when words are } \\
\text { presented in conversational style rather } \\
\text { than formal style. }\end{array}$ \\
\hline $\begin{array}{l}\text { Voice } \\
\text { principle }\end{array}$ & $\begin{array}{l}\text { People learn better when words are } \\
\text { spoken in a non-accented human voice } \\
\text { than in machine voice or accented voice. }\end{array}$ \\
\hline $\begin{array}{l}\text { Signaling } \\
\text { principle }\end{array}$ & $\begin{array}{l}\text { People learn better when the voice signals } \\
\text { important words rather than when there } \\
\text { are no signals. }\end{array}$ \\
\hline principle & $\begin{array}{l}\text { People learn better when they can control } \\
\text { the pace of presentation than when they } \\
\text { receive a continuous presentation. }\end{array}$ \\
\hline $\begin{array}{l}\text { People learn better when they receive } \\
\text { pre-training on each component rather } \\
\text { than no pre-training. }\end{array}$ \\
\hline pringing
\end{tabular}

\section{Needs Assessment}

Prior to accepting a project, a needs assessment is conducted in two steps; the first requires the prospective stakeholder division to complete and submit an Initiative Request Form (IRF), typically followed by a meeting with all involved stakeholders in which further details are explored and confirmed. The IRF serves as an excellent tool to initiate project discussion and to provide the basic information required to justifiably approve a project. As a tool customized to the particular functions of CFSA, the IRF goes further than a conventional needs

assessment in identifying the performance gap and other related factors, in containing the information within the framework of relevance for CFSI.

Gathering Content from SMEs

With the nature of course content spanning the work of different divisions, one of the greatest challenges is to determine appropriate Subject Matter Experts (SMEs). Depending on the course, a decision has to be made whether SMEs can be assigned from another stakeholder division within the department or whether the hiring is to be outsourced. While the latter option requires a lengthy contracting process initially, it can be relatively more time efficient overall due to internal SMEs having to multi task between other priorities and commitments.

There is a possibility that opting for internal SMEs can require more time to be allocated in working and collaborating with the SMEs and in accomplishing the necessary tasks while respecting deadlines.

Once the SMEs have been appointed or hired, a Master Design Chart (MDC) can be created to give an overview of
TABLE IV: IDENTIFICATION FACTORS IN THE INITIATIVE REQUEST FORM

\begin{tabular}{|l|}
\hline Business requirement/problem/issue \\
\hline Who and what is affected, target audience \\
\hline How it was determined that a course/tool/program is required \\
\hline $\begin{array}{l}\text { Planned result/goal/objectives of the training, estimated scope, } \\
\text { status of the content, evaluation strategy }\end{array}$ \\
\hline $\begin{array}{l}\text { Business Planning Objective: How proposed initiative fits in } \\
\text { with departmental priorities }\end{array}$ \\
\hline $\begin{array}{l}\text { Key Business Dates and Drivers: key business requirements } \\
\text { dates which are either desirable or mandatory to be met (any } \\
\text { legislative dates if applicable should be identified) }\end{array}$ \\
\hline Business Line: business lines that are supported by the project \\
\hline $\begin{array}{l}\text { Funding: Source of funding (include amount) needed for this } \\
\text { initiative from relevant section/division/branch/sector/mission }\end{array}$ \\
\hline $\begin{array}{l}\text { Consultations: Branches/Organizations consulted for the } \\
\text { preparation of this document (include name and title) }\end{array}$ \\
\hline $\begin{array}{l}\text { Reference Documentation: Pertinent/relevant documents } \\
\text { currently available (such as Business Process Models, Website } \\
\text { address, RFP, Business Case, etc.) }\end{array}$ \\
\hline
\end{tabular}

the entire course with such pertinent information as performance objectives and topics to cover. Some rules that should be considered for writing performance objectives include:

- $\quad$ Performance objectives must be written for learned outcomes and not evaluate students' opinions or judgments;

- $\quad$ The objective must be student-centered and at no time should the title of teacher, instructor and the like, be included in the objective;

- The selected behavior must be appropriate for the required skill to be learned;

- Terms should be used that describe behaviors that can be measured;

- Performance objectives must be attainable and realistic;

- Performance objectives are not written for examinations;

- $\quad$ Students must be evaluated in the same manner in which they are instructed;

- Performance objectives are not written as an activity [3].

From the performance objectives, the overall structure for the course can be derived, including enabling objectives; sub-enabling objectives; and learning outcomes. These can all be included in the MDC. The MDC also helps in determining specific areas that require content and provides direction towards potential SMEs. It is also of great assistance in developing flowcharts for job processes of target learners. Flowcharts reveal the structure and sequence of the instruction; they show how the various enabling objectives are taught and how the learner moves through them to reach the terminal objective [6]. Flowcharts help outline the functional procedure for their work and illustrate possibilities for content required for the course.

When the content has been determined and compiled, it can require some level of quality assurance, particularly in the format of presentation. From discerning between primary and secondary content to the style of writing employed by the SMEs, there is often a need for validation. In many cases, the services of a technical writer or editor are necessary to appropriately frame the content in a single consistent format and to make the text more rich, concise and effective in 
delivery, without aversely affecting the meaning or the message being expressed. The work can require much management in working with the technical writer or editor, as well as with the SMEs, to ensure the highest level of quality without diminishing transfer of knowledge as per the learning objectives of the online course.

\section{Developing the Storyboard}

Once the course content is determined and approved, the storyboard is developed for the course. As storyboards present a screen-by-screen description of the course design, they should include the complete primary text and secondary text, images, graphics, links and audio- video scripts as they will appear [6] [15]. Visuals are used to reinforce the text [11] in line with the cognitive-flexibility theory and the elaboration theory, both of which support the idea that presenting and re-presenting instructional content in multiple ways helps learners gain a better understanding [10]. This is also supported by the cognitive theory of multimedia learning and the redundancy principle, which proposes that people learn better from animation and spoken words so redundant material should be eliminated [11]. As well, many studies that compared lessons that used text alone to teach content with lessons that added relevant visuals to the text have shown that the versions with graphics do improve learning [14]. As such, designers should rely primarily on visual displays to communicate their message, at the same time de-emphasizing lengthy text passages [12]. All of this helps the storyboard express the eventual course interface as much and as accurately as possible.

\section{Designing Activities}

One of the main features of CFSA courses is practicality in better preparing learners with job expectations. Computer-based simulation is also a valuable tool for contemporary problem based approaches, particularly in the development of practical skills and in areas where experiential learning may not be possible due to time, cost or operational constraints [16]. As supported by the cognitive-flexibility theory and the elaboration theory [10], the use of interactive online learning activities provides the students with hands-on experiences that allow them to better understand the practices and theories of the course [7]. Activities are designed such that they help make the courses interactive and, at the same time, simulate and present real-life situations [7] [9]. Adding graphics, animation, video and audio to computer-based learning increases the realism of the environment and helps maintain learner motivation [18]. Scenarios and case-based activities are often used for simulation purposes. Additionally, audio voiceovers are oftentimes used in online courses in line with the cognitive theory of multimedia learning, which states spoken words can result in better understanding, and hence better transfer test performance, than printed words [11].

These are followed up with questions to confirm knowledge transfer related to performance objectives. Answer choices for questions are made straightforward, unambiguous, and plausible; some questions focus on recall knowledge but others are presented so that they require learners to analyze and interpret [17].

Conducting Evaluations

Upon completion of programming of the online course, pilot testing and focus group sessions are conducted with target learners to obtain comments and feedback on the course. Formative evaluations are the collection of data and information during the development of instruction which can be used to improve the effectiveness of the instruction [19]. Early pilot tests are done to help determine whether objectives are being achieved in the formative stages of the project, instead of waiting towards the end. They provide a chance to test ideas and implement changes before completing the entire course [20].

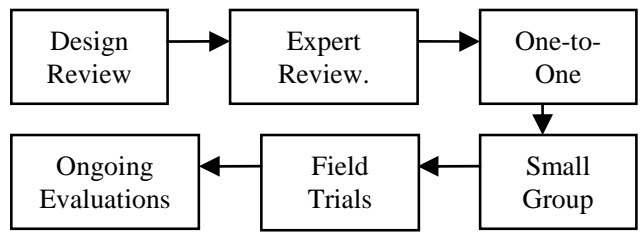

Fig. 2. Dick \& Carey's 6 stages of formative evaluation

It is important to get feedback from potential learners to evaluate how courses will be received. The pilot tests and focus group sessions help identify many important issues, particularly those pertaining to the interface, navigation, content, activities and overall look. Dick \& Carey's six stages of formative evaluation are used in conducting pilot testing and focus group sessions for each course [19].

In doing Summative Evaluations, CFSI uses the Kirkpatrick Four Levels Evaluation Model to evaluate learning.

An online questionnaire is filled out online by learners immediately after completing a course; an average of 60 percent of participants typically submit the questionnaire. The data from the Level 1 evaluation forms are compiled and used to improve courses when the time comes for their yearly revision.

Level 2 evaluations serve to provide information if and how much participants learned from a course. A final test is included at the end of the course, its items based on the learning objectives announced at the beginning of the course. Learners who score below the pass mark can go back to the course contents and retake the test. Learners who are confident that they already know some of the contents can skip some sections of the course and take the test. Passing the final assessment triggers an email notification of both the participant and staff at CFSA who manage training data. Level 2 evaluations can also show that some of the content may not be explained well enough or that a question in the assessment needs to be revised, which again feeds in the next yearly revision.

TABLE V: KIRKPATRICK FOUR LEVELS EVALUATION MODEL

\begin{tabular}{|c|} 
Level 1: Reaction \\
To what degree participants react favorably to the training \\
\hline $\begin{array}{c}\text { Level 2: Learning } \\
\text { skills, attitudes, confidence, and commitment based on their } \\
\text { participation in a training event }\end{array}$ \\
Level 3: Behavior \\
To what degree participants apply what they learned during \\
training when they are back on the job \\
Level 4: Results \\
To what degree targeted outcomes occur as a result of the \\
training event and subsequent reinforcement
\end{tabular}


Level 3 evaluations are currently being organized. Considering that DFAIT employees are very mobile, it can be challenging to follow up with participants of a course once they are on the job for which they were trained. A variety of complementary tools can be used:

- Online questionnaires sent to the participants, their peers or their managers;

- Virtual focus groups (by audio or web conference)

- Individual interviews (in person or on the phone)

The rich qualitative data collected from level 3 evaluations provide information about the quality of the course and about its relevance for the target audience.

\section{CONCLUSION}

Through the work of CFSA, the CFSI has successfully evolved and integrated an online learning-focused systemized blended learning model. This approach is synchronized with the growth of global eLearning trends and has effectively led to an increase in time and cost efficiency, while maximizing post-training results in regard to knowledge transfer. As we move forward in implementing Level 3 evaluations, we will be able to better assess how the training provided improves work performance and gauge the success in achieving desired outcomes.As the eLearning industry and learning technologies continue to evolve at a rapid pace, so does the approach to education at DFAIT with the commitment to maintain advancement and ensure expertise in the work of Canadian government officials across the world.

\section{REFERENCES}

[1] M. Nycz and E. Cohen, "The basics for understanding eLearning,” in Principles of effective online teaching, N. Buzzetto- More, Ed. Santa Rosa: CA, Informing Science Press, 2007, pp. 1-17.

[2] R. Clark, "Six Principles of Effective eLearning: What Works and Why," in Learning Solutions e-Magazine, 2002, pp. 1-9.

[3] F.R. Koontz, H. Li, and D.P. Compora, Designing Effective Online Instruction. Lanham, Maryland: Rowman \& Littlefield Education, 2006.

[4] R. Dagada and M. Jakovljevic, "ELearning strategies and tools in the corporate training environment,” Annual research conf. South African inst. of computer scientists and information technologists on IT research in developing countries, vol. 75, 2004, pp 194-203.

[5] S. Alessi and S. Trollip, Computer-based instruction: Methods and Development. Englewood Cliffs, NJ: Prentice Hall, 1985.

[6] S. Alessi and S. Trollip, Multimedia for Learning: Methods and Development. Needham, MA: Allyn \& Bacon, 2001.

[7] J. Van Keuren, Web-Based Instruction: A Practical Guide for Online Courses. Oxford: Rowman \& Littlefield Education, 2006.

[8] M.J. Rosenberg, ELearning: Strategies for Delivering Knowledge in the Digital Age. New York: McGraw-Hill, 2001.

[9] C.M. Adrian, "Developing a Learning Environment: Applying Technology and TQM to Distance Learning” in Web-Based
Instructional Learning, M. Khosrow-Pour, Ed. London: IRM Press, 2002, pp. 43-58.

[10] H. Wang and D.L. Gearhart, Designing and Developing Web-Based Instruction. New Jersey: Pearson Education Inc., 2006.

[11] R.E. Mayer, “Ten Research-Based Principles of Multimedia Learning” in Web-Based Learning: Theory, Research, and Practice, H.F. O’Neil and R.S. Perez, Eds. Mahwah, NJ: Lawrence Erlbaum Associates, Inc., 2006, pp. 371-390.

[12] L.H. Berry, "Cognitive Effects of Web Page Design,” in Web-Based Instructional Learning, M. Khosrow-Pour, Ed. London: IRM Press, 2002, pp. 90-109.

[13] R.E. Clark, D.F. Feldon, K. Howard, and S. Choi, "Five Critical Issues for Web-Based Instructional Design Research and Practice," in Web-Based Learning: Theory, Research, and Practice, H.F. O’Neil and R.S. Perez, Eds. Mahwah, NJ: Lawrence Erlbaum Associates, Inc., 2006, pp. 343-370

[14] R. Clark and C. Lyons, "More than just eye candy: Graphics for eLearning,” in ELearning Developers’ Journal, 2003. Retrieved from http://www.elearningguild.com/

[15] C. McCormack and D. Jones, Building a Web-based Education System. New York: Wiley Computer Publishing, 1998.

[16] B.M Garrett and G. Roberts, "Employing Intelligent and Adaptive Methods for Online Learning,” in E-Education Applications: Human Factors and Innovative Approaches, C. Ghaoui, Ed. Hershey, PA: Information Science Publishing. 2004, pp. 208-219.

[17] G.B. Randolph, D.A. Swanson, D.O. Owen, and J.A. Griffin, “Online Student Practice Quizzes and a Database Application to Generate Them,” in Web-Based Instructional Learning, M. Khosrow-Pour, Ed. London: IRM Press, 2002, pp. 142-149.

[18] B.M Garrett and R. Francis, "The Orientation and Disorientation of E-Learners," in E-Education Applications: Human Factors and Innovative Approaches, C. Ghaoui, Ed. Hershey, PA: Information Science Publishing. 2004, pp. 248-274

[19] W. Dick and L. Carey, The systematic design of instruction. New York, New York: Harper and Collins, 1996.

[20] V. Landau, "Formative Evaluation Planning”, in Developing an Effective Online Class, 2001. Retrieved from http://www.roundworldmedia.com/cvc/module10/notes10.html

S. Wasty was born in Canada and holds a Masters in Education Technology from Concordia University, Montreal, Canada and is currently pursuing a doctorate. His research interests include the use of low-cost tools and technologies combined with a critical approach for change management, the culture of the computer and education through multimedia, computers in education, and the development of skills for disadvantaged communities in lesser developed regions.

He works for the Department of Foreign Affairs and International Trade Canada and is currently an Education Specialist at the Canadian Foreign Service Institute, where, among his different responsibilities, he manages the design and development of online projects.

D. Renié has lived in Ottawa, Canada, since 1995. Born in France, she holds a Ph. D. in Linguistics from Université Blaise Pascal, Clermont-Ferrand, France. She conducted her post-doctoral research in applied linguistics at the University of Ottawa, focusing on the acquisition of second language vocabulary using multimedia technology. She also taught part-time at the University of Ottawa.

In 2002, she joined the Canadian Foreign Service Institute as an Education Specialist within the Centre for Foreign Languages. She managed the design and development of online language courses in ten languages. In 2008, she became a Senior eLearning Advisor in the newly created Centre for Learning Advisory Services, eLearning and Administration, where she has managed the design and development of online courses in various area of International Affairs training. 